\title{
Получение и сравнительный анализ свойств полимерных \\ наноструктурированных пленок \\ на основе различных органических \\ полимеров и наночастиц серебра
}

\section{Synthesis and comparative analysis of properties of nanostructured polymer films based on various polymers and silver nanoparticles}

\section{O. A. Фарус}

Оренбургский государственный

педагогический университет, Россия

Поступила в редакцию 18.07.2019, принята к печати 29.09.2019

\section{O. A. Farus}

Orenburg state

pedagogical University, Russia

\section{Абстракт}

Синтезированы гибридные нанокомпозитные полимерные пленки, модифицированные наночастицами серебра. Синтез осуществлялся с помощью реакций контролируемого осаждения, которые лежат в основе золь-гель технологии. Для синтеза наночастиц серебра использовали раствор нитрата серебра, лимонной кислоты, полимеров (синтетических и натуральных) и глицерина. Изучены оптические и антибактериальные свойства полученных наноструктурированных полимерных материалов. Опытные образцы, содержащие поливиниловый спирт и кукурузный крахмал, обладают свойствами, важными для потребителя (прочные, тонкие, стойкие к жирам), являются водорастворимыми, экологически безопасными, обладают низким коэффициентом светопропускания и проявляют фунгицидную активность, которая была доказана экспериментально.

\section{Abstract}

Hybrid nanocomposite polymer films modified by silver nanoparticles were synthesized. The basis of this process is the sol-gel technology. For the synthesis of silver nanoparticles, a solution of silver nitrate, citric acid, polymers (synthetic and natural) and glycerin was used. Optical and antibacterial properties were investigated for the obtained nanostructured polymeric materials. The films containing polyvinyl alcohol and corn starch have properties important for consumers. They turned out to be strong, thin, resistant to fats, watersoluble, environmentally safe, have a low light transmission coefficient

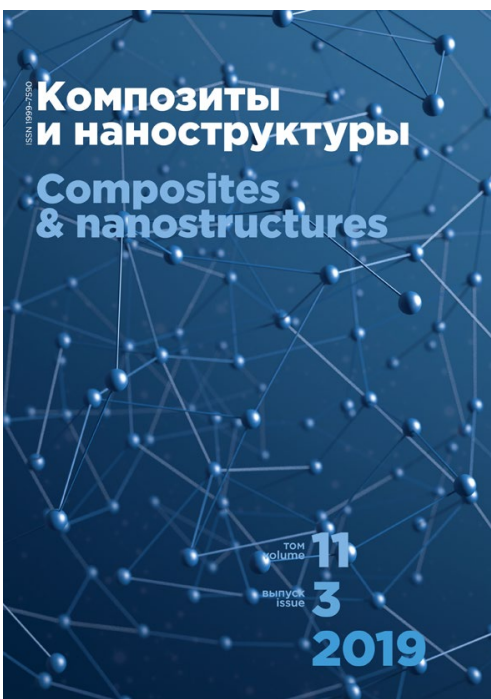

